\title{
SITA MARITAL HARTA BERSAMA DALAM PERKARA PERCERAIAN DI PENGadILAN AgAMA
}

\author{
Edi Gunawan, Budi Rahmat Hakim, Risdianti Bonok \\ IAIN Manado| JI. Ringroad Kawasan I, Kota Manado, Sulawesi Utara \\ UIN Antasari Banjarmasin | Jl. Jend. Ahmad Yani Km. 4,5 Banjarmasin \\ IAIN Manado | Jl. Ringroad Kawasan I, Kota Manado, Sulawesi Utara \\ edigunawan@iain-manado.ac.id
}

\begin{abstract}
The process of resolving marital seizure applications on joint assets in a divorce case at the Religious Court is carried out with stages starting from the application of the marital seizure to objects, both movable and immovable goods. It is highly dependent on concrete and demonstrable reasons regarding seizure placement in trial face. If the seizure request can be granted by the panel of judges according to strong evidence and proven in the trial, the panel of judges can conduct marital seizure by ordering the registrar to be assisted by the bailiff to confiscate movable or immovable items to be recorded. Marital seizure contained in the object of the dispute in the contents of the claim with the local government present. Whereas judicial legal considerations regarding marital seizure applications, the panel of judges, firstly looks at the facts from the trial. If the seizure is granted then enough reason for seizure applicants to be placed marital seizure. And if the seizure application is rejected and there is no enough reason to place the marital seizure by the panel of judges because there was no concern, the defendant will move or transfer the object of the dispute to another person who was carried out through a hearing outside the Religious Court which is also called the local hearing.
\end{abstract}

Keywords: Marital Seizure, Joint Property, Case, Divorce

\begin{abstract}
Abstrak: Proses penyelesaian permohonan sita marital terhadap harta bersama dalam perkara perceraian di Pengadilan Agama dilakukan dengan tahapan-tahapan mulai dari permohonan peletakan sita marital terhadap objek, baik barang bergerak maupun tidak bergerak, sangat bergantung pada alasan yang kongkrit dan dapat dibuktikan mengenai peletakan sita di muka persidangan, apabila permohonan sita dapat dikabulkan oleh majelis hakim sesuai bukti yang kuat dan dibuktikan dalam persidangan maka majelis hakim dapat melakukan sita marital
\end{abstract}

\footnotetext{
AL-DAULAH: JURNAL HUKUM DAN PERUNDANGAN ISLAM VOLUME 8, NOMOR 2, OKTOBER 2018$$
\text { p-ISSN 2089-0109; e-ISSN 2503-0922 }
$$ 
dengan memerintahkan Panitera yang dibantu oleh jurusita untuk melakukan sita baik barang bergerak atau tidak bergerak untuk dicatat, Selanjutnya panitera membuat berita acara sita marital yang terdapat dalam objek sengketa dalam isi gugatan dengan dihadirkan pemerintah setempat. Sedangkan pertimbangan hukum hakim mengenai permohonan sita marital, majelis hakim terlebih dahulu melihat pada fakta-fakta yang lahir dalam persidangan, apabila sita dikabulkan maka cukup alasannya bagi pemohon sita untuk diletakkan sita marital dan apabila permohonan sita ditolak maka tidak cukup alasan untuk diadakan peletakkan sita marital oleh majelis hakim karena tidak ditemukan kekhawatiran tergugat akan memindahkan atau mengalihkan objek sengketa kepada orang lain yang dilakukan melalui sidang di luar gedung Pengadilan Agama yang dinamakan dengan sidang pemeriksaan setempat.

Kata Kunci: Sita Marital, Harta Bersama, Perkara, Perceraian

\section{Pendahuluan}

Berdasarkan Undang-Undang No.1 Tahun 1974 dinyatakan bahwa perkawinan adalah ikatan lahir batin antara seorang pria dengan seorang wanita sebagai suami istri dengan tujuan membentuk keluarga (rumah tangga) yang bahagia dan kekal berdasarkan Ketuhanan Yang Maha Esa. ${ }^{1}$

Pasangan suami istri yang hidup dalam sebuah perkawinan akan memperoleh harta, baik karena harta tersebut miliknya sebelum perkawinan itu dilakukan, maupun adanya harta-harta yang diperoleh karena telah dilaksanakannya perkawinan tersebut, atau harta yang didapat karena perkawinan. Harta yang diperoleh selama perkawinan merupakan harta bersama, seperti diatur pada UU No. 1/1974 tentang Perkawinan Pasal 35 ayat $(1)^{2}$. Harta benda yang diperoleh selama perkawinan menjadi harta bersama.

Apabila dalam sebuah perkawinan terjadi proses perceraian di pengadilan, maka hukum memberikan perlindungan terhadap harta bawaan yang didapat oleh suami isteri di mana selama

'Lembaran Negara RI, Undang-Undang Nomor I Tahun 1974 Tentang Perkawinan.

¿Lembaran Negara RI, Undang-undang No. I Tahun 1974 tentang Perkawinan Pasal 35. 
proses pengadilan berjalan harta bersama suami isteri perlu dilakukan sita jaminan. Keperluan dari pada sita jaminan agar ada garansi terhadap hak atau penyerahan benda yang di dalam amar putusan pengadilan setelah adanya putusan pengadilan, tidak luput dari ada atau tidaknya benda itu masih ada. Hal ini juga memberikan jaminan atau kemudahan guna pelaksanaan eksekusi apabila putusan pengadilan telah mempunyai kekuatan hukum tetap.

Penggugat yang melakukan gugatan perceraian biasanya dalam petitumnya sudah dimasukkan materi sita jaminan (conservatoir berslag), hal ini tentu untuk menjamin hak Penggugat apabila perkara Penggugat dimenangkan oleh pengadilan. Menurut Pasal 24 ayat 2 huruf c PP No. 9 Tahun 1975 disebutkan bahwa selama berlangsungnya gugatan perceraian atas permohonan Penggugat atau Tergugat pengadilan dapat menentukan hal-hal yang perlu untuk menjamin terpeliharanya barang-barang yang menjadi hak bersama suami isteri atau barang-barang yang menjadi hak suami atau barang-barang yang menjadi hak isteri. ${ }^{3}$

Hakekatnya adalah bahwa tindakan atau upaya penyitaan terhadap harta perkawinan dan tindakan yang dianggap menjamin terpeliharanya harta selama proses perkara perceraian berlangsung di pengadilan adalah upaya positif, kepentingan para pihak supaya barang-barang yang diperoleh dalam perkawinan tidak akan hilang. Artinya dapat dilakukan sita marital oleh pihak pengadilan walaupun sita marital tersebut bukanlah untuk menjamin suatu tagihan uang atau penyerahan barang, melainkan menjamin agar barang yang disita tidak dijual. Fungsinya hanya untuk melindungi hak pemohon selama pemeriksaan sengketa perceraian di pengadilan berlangsung antara Penggugat dan Tergugat, dengan menyimpan atau membekukan barang-barang

${ }^{3}$ Lembaran Negara RI, Peratutan Pemerintah No. 9 Tahun 197 Tentang Gugatan Perceraian. 
yang tersita, agar jangan sampai jatuh ke tangan pihak lain atau pihak ketiga yang tidak berkepentingan dengan barang tersebut.

Sita marital merupakan suatu pembagian harta bersama antara suami isteri yang akan melakukan perceraian. Selama proses perceraian itu masih berlangsung, gugatan sita marital dapat diajukan. ${ }^{4}$ Sita marital merupakan bagian dari sita jaminan, maka alasan meminta sita marital sama dengan alasan meminta sita jaminan, antara lain ada persangkaan yang beralasan dan contohnya dalam gugatan perceraian, Tergugat dianggap akan menggelapkan barang-barang, sehingga hal itu akan merugikan Penggugat. Pembekuan harta bersama di bawah penyitaan, berfungsi untuk mengamankan atau melindungi keberadaan dan keutuhan harta bersama atas tindakan yang tidak bertanggung jawab dari Tergugat.

Sita marital atau sita harta bersama, memiliki tujuan utama untuk membekukan harta bersama suami-isteri melalui penyitaan, agar tidak berpindah kepada pihak ketiga selama proses perkara atau pembagian harta bersama berlangsung. Pembekuan harta bersama di bawah penyitaan, berfungsi untuk mengamankan atau melindungi keberadaan dan keutuhan harta bersama atas tindakan yang tidak bertanggung jawab dari Tergugat.

\section{Pengertian Sita Marital (Marital Beslag)}

Sita marital (marital beslag) adalah sita yang diletakkan atas harta bersama suami-istri baik yang berada di tangan suami maupun yang berada di tangan istri apabila terjadi sengketa perceraian. Apabila terjadi perkara perceraian berlangsung, maka para pihak berhak mengajukan permohonan sita atas harta perkawinan dan sita yang demikian disebut dengan Sita Marital. ${ }^{5}$ Sita marital tidak boleh dijalankan secara partia (sebagian-

${ }^{4}$ http://Atmajaya.ac.id. 2015. Tinjauan Yuridis Gugatan Sita Marital terhadap Harta Bersama menurut Peraturan Hukum di Indonesia. https://ib.atmajaya.ac.id/default.aspx? tablD $=6|\& s r c=k \& i d=| 55074$. Diakses 9 Mei 2017.

5M. Yahya Harahap, Hukum Acara Perdata: Permasalahan dan Penerapan Conservatoir Beslag (Sita Jaminan), (Cet. I; Jakarta: Pustaka, 1987), 145. 
sebagian). Sita Marital merupakan salah satu bentuk dari sita jaminan (conservatoir beslag) yang bersifat khusus, dan hanya dapat ditetapkan terhadap harta perkawinan, yakni harta bersama apabila terjadi perceraian di antara suami dan istri.

Setiap sita mempunyai tujuan tertentu, dalam sita revindikasi bermaksud menuntut pengembalian barang yang bersangkutan kepada Penggugat sebagai pemilik, sedangkan sita jaminan (Conservatoir Beslag) bertujuan menjadikan barang yang disita sebagai pemenuhan pembayaran utang Tergugat. Tujuan sita marital berbeda dengan yang disebutkan diatas bukan untuk menjamin tagihan pembayaran kepada Penggugat (suami atau istri), juga bukan untuk menuntut penyerahan hak milik (revindikasi) akan tetapi tujuan utamanya untuk membekukan harta bersama suami istri melalui penyitaan, agar tidak berpindah kepada pihak ketiga selama proses perkara. ${ }^{6}$ Secara lebih khusus, tujuan dari Sita Marital adalah untuk menjamin agar harta perkawinan tetap utuh dan terpelihara sampai perkara mendapat putusan yang berkekuatan hukum tetap. ${ }^{7}$

Penyitaan terhadap harta bersama, baik Penggugat atau Tergugat (suami-istri), dilarang memindahkannya kepada pihak lain dalam segala bentuk transaksi. ${ }^{8}$ Dengan adanya penyitaan tersebut, apabila terjadi tindakan tergugat untuk mengasingkan atau mengalihkan atau mengoper barang-barang yang disita adalah tidak sah, dan merupakan suatu tindakan pidana.

Adanya pembekuan harta bersama dibawah penyitaan, berfungsi untuk mengamankan atau melindungi keberadaan dan keutuhan harta bersama atas tindakan yang tidak bertanggung jawab dari Tergugat. Sehubungan dengan itu titik berat penilaian yang harus dipertimbangkan pengadilan atas permintaan sita

${ }^{6}$ Sudikno Mertokusumo, Hukum Acara Perdata Indonesia, (Cet. 2 ; Yogyakarta: Liberty, 1999), 64.

${ }^{7}$ Abdul Manan, Penerapan Hukum Acara Perdata di Lingkungan Peradilan Agam, a (Cet.4; Jakarta: Kencana, 2006), 41.

${ }^{8}$ Sudikno Mertokusumo, Hukum Acara Perdata Indonesia, 164. 
marital adalah pengamanan atau perlindungan atas keberadaan harta bersama. Penilaian ini jangan terlampau dititikberatkan pada faktor dugaan atau persangkaan akan adanya upaya Tergugat untuk menggelapkan barang tersebut, tetapi lebih diarahkan pada masalah pengamanan dan perlindungan harta bersama.

\section{Pengaturan Sita Marital}

Sita Marital tidak terdapat di dalam HIR atau RBg melainkan hanya dijumpai di dalam BW (Burgerlijk Wetboek) dan Rsv (Reglement op de Burgerlijke Rechtsvordering). ${ }^{9}$ Pengaturan sita marital dapat ditemukan dalam beberapa peraturan perundangundangan, antara lain yang terdapat dalam Pasal $190 \mathrm{KUH}$ Perdata yang berbunyi: "Sementara perkara berjalan dengan izin Hakim, istri boleh mengadakan tindakan-tindakan untuk menjaga agar harta kekayaan persatuan tidak habis atau diboroskan". ${ }^{10}$ Ketentuan tersebut dulunya berlaku bagi golongan Eropa dan Tionghoa. Tetapi sejak UU No.1 tahun 1974 berlaku, Pasal 66 menegaskan segala ketentuan KUH Perdata mengenai Perkawinan dinyatakan tidak berlaku lagi. Namun demikian ketentuan Pasal $190 \mathrm{KUH}$ Perdata tersebut, dapat dijadikan bahan orientasi sebagai kedudukan dalam hukum adat tertulis.

Dalam pasal 24 ayat (2) huruf c PP No. 9 Tahun 1975 dinyatakan:

"Selama berlangsungnya gugatan perceraian atas permohonan penggugat atau tergugat atau berdasarkan pertimbangan bahaya yang mungkin timbul, pengadilan dapat mengijinkan dan menentukan hal-hal yang perlu untuk menjamin terpeliharanya barang-barang yang menjadi hak bersama suami istri“.

Sita Marital lazim berlaku di lingkungan Peradilan Umum, namun menurut pasal 78 huruf c UU No. 7 tahun 1989 jo. UU No 3

${ }^{9}$ Roihan A. Rasyid, Hukum Acara Peradilan Agama, (Cet.2; Jakarta: PT.Raja Grafindo Persada, 2003), 208.

IOR. Subekti, R. Soesilo, Kitab Undang-Undang Hukum Perdata, (Bandung: Pradnya Paramita), 60. 
Tahun 2006 dinyatakan bahwa lingkungan Peradilan Agama pun telah memiliki aturan positif lembaga sita marital. Bahkan sita marital tersebut dalam lingkungan peradilan agama, tidak hanya diatur dalam Pasal 78 UU No. 7 Tahun 1989 jo. UU No. 3 Tahun 2006, tetapi juga dalam Pasal 136 ayat (2) huruf b Kompilasi Hukum Islam (KHI), yang sama bunyinya dengan Pasal 24 Ayat (2) huruf c PP No. 9 Tahun 1975 dan Pasal 78 huruf c UU No. 7 tahun 1989 jo. UU No. 3 Tahun 2006.

Dengan demikian, landasan penerapan sita marital dalam lingkungan Peradilan Agama telah diatur dalam berbagai bentuk peraturan perundang-undangan. Pasal $823 \mathrm{Rv}$ menyebutkan: "Tindakan-tindakan yang boleh dilakukan sehubungan dengan Pasal $190 \mathrm{KUH}$ Perdata adalah penyegelan, pencatatan harta kekayaan dan penilaian barang-barang, penyitaan jaminan atas barang-barang bergerak bersama atau jaminan atas barang- barang tetap bersama".

Pasal tersebut merupakan salah satu di antara beberapa pasal lainnya yang mengatur tentang sita marital. Ketentuannya mulai dari Pasal 823-830 Rv. Maka dapat dilihat bahwa pengaturan sita marital dalam Rv sangat luas. Sebaliknya dalam UU No.1 tahun 1974 dan PP No. 9 tahun1975 hanya terdiri dalam satu (1) pasal. Sedangkan dalam HIR dan RBG sama sekali tidak diatur mengenai sita marital.

Terkait ketentuan sita marital ini dalam Kompilasi Hukum Islam (KHI) juga dinyatakan dalam Pasal 95 Ayat (1) dan Ayat (2) bahwa ;

Dengan tidak mengurangi ketentuan Pasal 24 Ayat (2) Huruf (c), Peraturan Pemerintah Nomor 9 Tahun 1975 dan Pasal 136 Ayat (2), suami atau istri dapat meminta Pengadilan Agama untuk meletakkan sita jaminan atas harta bersama tanpa adanya permohonan gugatan cerai, apabila salah satu melakukan perbuatan yang merugikan dan membahayakan harta bersama seperti judi, mabuk boros dan sebagainya. 
Dalam Pasal 136 Ayat (2) Huruf (b) Kompilasi Hukum Islam juga menyatakan ketentuan terkait sita marital ini bahwa selama berlangsungnya gugatan perceraian, atas permohonan penggugat dan tergugat Pengadilan Agama dapat menentukan hal-hal yang perlu untuk menjamin terpeliharanya barang-barang yang menjadi hak bersama suami-istri atau barang- barang yang menjadi hak istri.

Seperti yang telah diuraikan sebelumnya sita marital adalah salah satu jenis sita jaminan (conservatoir beslag), oleh karena itu segala ketentuan yang berlaku pada sita jaminan, berlaku sepenuhnya pada sita marital. Mulai dari pengajuan permohonan, dan tata cara pelaksanaannya. ${ }^{11}$

Ketentuan yang terdapat di dalam HIR (Herziene Inlandsch Reglement), RBg (Rechtreglement Voor De Buitengwesten), B.Rv (Reglement Op De Burgerlijke Rechvordering), dan sumber hukum acara yang berlaku di Pengadilan Umum, kecuali hal-hal yang telah diatur secara khususnya oleh Undang-Undang Nomor 7 Tahun 1989 jo. Undang-Undang Nomor 3 Tahun 2006 dapat digunakan pada sita marital yang diajukan kepada Pengadilan Agama, sesuai Pasal 54 Undang- Undang Nomor 7 Tahun 1989 jo. Undang-Undang Nomor 3 Tahun 2006 yang menyatakan bahwa hukum acara yang berlaku di Pengadilan Agama adalah hukum acara perdata pada Pengadilan Umum, kecuali yang telah diatur secara khusus dalam undang-undang ini.

\section{Ruang Lingkup Penerapan Sita Marital}

Sita marital dapat diterapkan dalam beberapa perkara berikut:

a. Perkara perceraian

Penerapan sita marital yang paling utama pada perkara perceraian. Apabila terjadi perkara perceraian antara suami istri, maka hukum akan memberi perlindungan kepada suami atau istri atas keselamatan keutuhan harta bersama. Dengan 
cara meletakkan sita di atas seluruh harta bersama untuk mencegah perpindahan harta bersama kepada pihak ketiga.

Sebagaimana yang diatur dalam Pasal 190 maupun Pasal $125 \mathrm{KUH}$ Perdata, hak untuk mengajukan sita marital hanya diberikan kepada istri. Hal itu sesuai dengan latar belakang yang digariskan Pasal $105 \mathrm{KUH}$ Perdata yang memberi kedudukan matriale macht (kepala persekutuan) kepada suami, dan sekaligus memberi hak dan wewenang kepada suami untuk mengurus dan menguasai harta kekayaan bersama dan harta istri dalam perkawinan. Menurut ketentuan tersebut dapat dipahami bahwa penguasaan harta bersama berada di tangan suami. Kepada istri diberi hak untuk meminta sita marital agar suami tidak leluasa menghabiskan harta bersama selama proses perkara masih berjalan.

b. Perkara pembagian harta bersama

Pada dasarnya persoalan sita harta bersama diperlukan apabila terjadi perkara antara suami dan istri. Secara hukum perkara yang mungkin timbul di antara suami istri yang erat kaitannya dengan harta bersama bukan hanya pada perkara perceraian tetapi juga pada perkara pembagian harta bersama. Seperti seorang suami yang mengajukan gugatan perceraian tanpa dibarengi tuntutan pembagian harta bersama. Terhadap gugatan itu, istri (selaku Tergugat) tidak mengajukan gugatan rekonvensi, menuntut pembagian harta bersama, selanjutnya gugatan perceraian dikabulkan. Dalam keadaan seperti itu apabila mantan suami atau istri ingin membagi harta bersama hanya dapat dilakukan melalui gugatan tentang pembagian harta bersama.

Dalam menjamin keutuhan dan keselamatan harta bersama selama proses perkara berlangsung, hanya dengan cara meletakkan proses sita marital di atasnya. Hal ini jika ditinjau dari segi penjaminan keberadaan harta bersama dalam pembagian harta bersama, sangat urgen meletakkan sita marital selama proses pemeriksaan berlangsung. Oleh karena 
itu sangat relevan menerapkan sita marital dalam perkara pembagian harta bersama.

c. Perbuatan yang membahayakan harta bersama

Sita marital yang dimaksudkan diatas diterapkan dalam perkara pembagian harta bersama. Jadi penerapannya bertitik tolak dari adanya perkara antara suami istri. Seolah-olah jika tidak terjadi perkara atau pembagian harta bersama, sita marital tidak berfungsi dan tidak dapat diterapkan dalam penegakkan hukum diantara suami istri. Ketentuan ini sesuai dengan isyarat yang dipahami dalam Undang-Undang No. 1 tahun 1974 dan PP No. 9 tahun 1975. Namun sebenarnya, jika berorientasi kepada ketentuan hukum yang ada maka sita marital dapat diterapkan penegakkannya di luar proses perkara perceraian atau pembagian harta bersama; oleh karena itu dimungkinkan menerapkannya di luar proses perkara, apabila terjadi tindakan yang membahayakan keberadaan harta bersama.

Penerapan demikian dapat berorientasi kepada ketentuan Pasal 186 KUH Perdata yang menyatakan bahwa selama perkawinan berlangsung suami atau istri (aslinya hanya disebut istri), dapat mengajukan permintaan sita marital terhadap hakim, namun permintaan itu harus berdasarkan alasan bahwa harta bersama berada dalam keadaan bahaya karena :

1) Adanya tindakan atau perbuatan dari suami atau istri yang nyata-nyata memboroskan harta bersama serta dapat menimbulkan akibat bahaya keruntuhan keluarga dan rumah tangga;

2) Tidak adanya ketertiban dalam mengelola dan mengurus harta bersama yang dilakukan suami atau istri yang dapat membahayakan eksistensi dan keutuhan harta bersama sebagaimana mestinya.

\section{Permohonan Sita Marital (Marital Beslag)}


Seperti yang telah diuraikan sebelumnya bahwa sita marital itu merupakan salah satu jenis dari sita jaminan (conservatoir beslag) yang bersifat khusus, oleh karena itu segala ketentuan yang berlaku pada sita jaminan, berlaku sepenuhnya juga pada sita marital. Mulai dari pengajuan permohonan dalam surat gugatan maupun yang diajukan secara terpisah dari pokok perkaranya hingga dalam tata cara pelaksanaannya. ${ }^{12}$

Hal yang dapat menjadi alasan untuk mengajukan sita marital sama dengan alasan pengajuan sita jaminan (conservatoir beslag) sebagaimana diatur dalam Pasal 227 Jo Pasal 197 HIR atau Pasal 261 Jo Pasal 206 Rbg. Alasan-alasan yang dimaksud adalah bahwa adanya persangkaan yang beralasan bahwa Tergugat akan menggelapkan barang- barang sehingga hal itu akan merugikan Penggugat. ${ }^{13}$ Kemudian yang berwenang untuk menilai unsur persangkaan adalah hakim, bukan Penggugat dan batas minimal yang dianggap bernilai untuk mengesahkan alasan persangkaan adalah apabila ada fakta yang mendukung persangkaan atau sekurang-kurangnya ada petunjuk-petunjuk yang membenarkan persangkaan, dan fakta atau petunjuk tersebut dinilai harus masuk akal. $^{14}$

\section{Tata Cara Pengajuan Sita Marital}

Dalam pengajuan permohonan sita marital, Penggugat mengajukan permohonan sita marital secara tertulis dalam surat gugatan, sekalipun bersamaan dengan pengajuan gugatan pokok kepada Pengadilan Agama. Pengajuan permohonan sita marital dalam bentuk ini, tidak dipisahkan dengan dalil gugatan atau gugatan pokok, keduanya bersatu dalam surat gugatan sekaligus

\footnotetext{
12M. Yahya Harahap, Kedudukan, Kewenangan dan Acara Peradilan Agama, 288-290.

13M. Yahya Harahap, Hukum Acara Perdata: Permasalahan dan Penerapan Conservatoir Beslag (Sita Jaminan), 36.

${ }^{14}$ M. Yahya Harahap, Hukum Acara Perdata: Permasalahan dan Penerapan Conservatoir Beslag (Sita Jaminan),38.
} 
jika permohonan sita marital disatukan bersamaan dengan surat gugatan. ${ }^{15}$

Dalam perumusan dalil gugatan yang merupakan landasan dari hal tersebut dapat diketahui layak atau tidaknya pengajuan permohonan sita marital. Hal itu dikarenakan dari perumusan dalil gugat serta uraian fakta dan peristiwa yang mendukung dalil gugat, maka permohonan sita marital serta alasan kepentingan akan lebih tepat dan lebih mudah dirumuskan permohonan sita serta alasan kepentingan penyitaan. di samping perumusan permohonan sita marital di akhir posita gugat, permohonan itu harus dipertegas lagi dalam petitum gugatan yang berisi permintaan kepada pengadilan, supaya sita marital yang diletakkan atas harta bersama dinyatakan sah dan berharga. ${ }^{16}$

Adapun bentuk pengajuan sita marital yang kedua dilakukan dalam bentuk "tersendiri", terpisah dari gugatan pokok perkara. Di samping gugatan perkara, Penggugat mengajukan permohonan sita marital dalam bentuk surat yang lain. Bahkan dimungkinkan dan dibolehkan melakukan pengajuan permohonan sita marital tersendiri secara lisan, meskipun bentuk permohonan sita marital secara lisan sering terjadi dalam praktek, namun kelangkaan praktek itu bukan berarti melenyapkan hak Penggugat untuk mengajukan permohonan sita marital secara lisan.

\section{Tata Cara Pelaksanaan Penyelesaian Sita Marital}

Pelaksanaan sita marital sama dengan tata cara pelaksanaan sita eksekusi (Eksekutorial Beslag) dengan demikian tata cara pelaksanaan Conservatoir Beslag dengan sita eksekusi diatur dalam

15M. Yahya Harahap, Hukum Acara Perdata: Permasalahan dan Penerapan Conservatoir Beslag, (Sita Jaminan), 24

16M. Yahya Harahap, Hukum Acara Perdata: Permasalahan dan Penerapan Conservatoir Beslag (Sita Jaminan), 25. 
Pasal 197 Ayat 2 sampai Ayat 6 HIR atau Pasal 209 RBg sebagaimana dinyatakan berikut: ${ }^{17}$

a. Pejabat yang berwenang untuk memerintahkan Conservatoir Beslag ialah Ketua Majelis atas nama Majelis Hakim yang memeriksa perkara yang bersangkutan dengan cara permohonan conservatoir beslag diperiksa dalam persidangan insidentil dan diperiksa dan diputus mendahului pokok perkara.

b. Berdasarkan hasil pemeriksaan insidentil dikeluarkan perintah kepada Panitera atau Juru Sita untuk melaksanakannya dan perintah tersebut dituangkan dalam bentuk "Surat Penetapan".

c. Pelaksanaan Conservatoir Beslag dilakukan di tempat letak barang yang dilaksanakan oleh Juru Sita dan dibantu oleh dua orang saksi.

d. Juru Sita membuat "Berita Acara" Conservatoir Beslag yang mencantumkan secara rinci satu persatu barang yang diconsevatoir beslag, jenis dan ukuran barang, kemudian membuat berita acara dihadapan tersita, apabila tersita tidak hadir maka berita acara diberitahukan kepadanya. Berita acara sita ditandatangani oleh juru sita dan dua orang saksi. Pembuatan berita acara merupakan syarat formil keabsahan conservatoir beslag.

Penjagaan conservatoir beslag diatur dalam Pasal 197 Ayat (9) HIR atau Pasal 212 RBg yakni:

1) Penjagaan conservatoir beslag barang bergerak tetap di tangan tersita ditinggalkan untuk disimpan pihak tersita atau dibawa ke tempat penyimpanan yang patut.

2) Penjagaan barang conservatoir beslag, tidak boleh diserahkan kepada pemohon sita.

\section{Akibat Hukum Sita Marital Terhadap Harta Bersama}

17M. Yahya Harahap, Hukum Acara Perdata: Permasalahan dan Penerapan Conservatoir Beslag (Sita Jaminan), 31 . 
Sita marital merupakan salah satu jenis atau pengkhususan dari "Sita Jaminan" (conservatoir beslag). Oleh karena itu, segala ketentuan yang berlaku pada sita jaminan (conservatoir beslag) berlaku sepenuhnya pada sita marital. ${ }^{18}$ Terkait dengan pemeliharaan harta bersama untuk menjaga keutuhannya dalam kasus sita marital harus diartikan meliputi seluruh harta bersama. Tidak boleh diartikan hanya untuk sebagian atau harta tertentu saja, jadi sita marital diletakkan meliputi seluruh harta bersama yang dimiliki oleh kedua belah pihak yang berperkara. ${ }^{19}$

Tujuan dari sita marital (sita harta bersama) itu sendiri antara lain untuk membekukan harta bersama suami istri melalui penyitaan, agar tidak berpindah kepada pihak ketiga selama proses perceraian/pembagian harta bersama berlangsung. Sedangkan fungsi dari dimohonkannya sita marital adalah untuk melindungi hak pemohon sita marital dengan menyimpan atau membekukan barang yang disita agar jangan sampai jatuh di tangan pihak ketiga. ${ }^{20}$

Kemudian apabila sita marital (marital beslag) mempunyai kekuatan hukum mengikat, diatur dalam Pasal 199 Ayat 1 HIR atau Pasal 214 Ayat 1 RBg., yaitu terhitung dari jam dan hari berita acara sita diumumkan, dan sejak saat itu dalam sita jaminan telah terkandung unsur akibat hukum. Yang mana bentuk dari akibat hukumnya ialah berwujud "batal demi hukum", yaitu "larangan" berupa:

a. Memindahkan kepada pihak ketiga dengan kata lain dilarang untuk menjual, menghibahkan, atau menukar barang yang menjadi sita marital.

b. Dilarang untuk membebankannya kepada pihak ketiga yakni dalam bentuk agunan, hipotik, gadai, dan sewa. ${ }^{21}$

18M. Yahya Harahap, Hukum Acara Perdata: Permasalahan dan Penerapan Conservatoir Beslag (Sita Jaminan), 94.

19M. Yahya Harahap, Kedudukan Kewenangan dan dan Acara Peradilan Agama, 284.

${ }^{20}$ Sudikno Mertokusumo, Hukum Acara Perdata Indonesia, 92.

${ }^{21}$ M.Yahya Harahap, Hukum Acara Perdata: Permasalahan dan Penerapan Conservatoir Beslag (Sita Jaminan), 94. 


\section{Proses Penyelesaian Sita Marital terhadap Harta Bersama dalam Perkara Perceraian di Pengadilan Agama Manado}

Sita marital atau sita jaminan, memiliki tujuan utama untuk membekukan harta bersama suami-isteri melalui penyitaan, agar tidak berpindah kepada pihak ketiga selama proses perkara atau pembagian harta bersama berlangsung. Pembekuan harta bersama di bawah penyitaan, berfungsi untuk mengamankan atau melindungi keberadaan dan keutuhan harta bersama atas tindakan yang tidak bertanggung jawab dari Tergugat. ${ }^{22}$

Sebagai pembanding, diberikan uraian tentang sita marital pada perceraian suami-isteri yang beragama Islam, yaitu sita marital bagi perceraian suami-isteri yang beragama Islam diatur Pasal 78 huruf c UU No. 50 Tahun 2009 tentang Peradilan Agama, Pasal 95 dan Pasal 136 ayat (2) Kompilasi Hukum Islam (KHI). Cara pelaksanaan sita marital dapat kita simpulkan dari pengaturan Pasal 78 huruf c UU Peradilan Agama Jo. Pasal 95 dan Pasal 136 ayat (2) KHI, yang secara lengkap mengatur sebagai berikut: 23

1. Pasal 78 huruf c UU No 50 Tahun 2009 tentang Peradilan Agama

Selama berlangsungnya gugatan perceraian, atas permohonan pengugat, pengadilan dapat menentukan hal-hal yang perlu untuk menjamin terpeliharanya barang-barang yang menjadi hak bersama suami isteri atau barang-barang yang menjadi hak suami atau barang-barang yang menjadi hak isteri.

2. Pasal 136 ayat (2) KHI

"Selama berlangsungnya gugatan perceraian, atau permohonan penggugat atau tergugat, Pengadilan Agama dapat :

a. Menentukan nafkah yang harus ditanggung oleh suami.

22M. Basir, Ketua Pegadilan Agama Manado, Wawancara, Manado, 13 Desember 2017.

${ }^{23}$ Burhanudin Mokodompit, Hakim Madya Utama Pegadilan Agama Manado, Wawancara, 14 Desember 2017. 
b. Menentukan hal-hal yang perlu untuk menjamin terpeliharanya barang-barang yang menjadi hak bersama suami isteri atau barang-barang yang menjadi hak suami atau barang-barang yang menjadi hak isteri."

Pasal 95 KHI memungkinkan untuk dilakukan sita marital oleh seorang suami/ isteri dalam suatu perkawinan tanpa melakukan gugatan perceraian. Sedangkan, Pasal 136 ayat (2) KHI mengatur sita marital yang dilakukan selama berlangsungnya sidang perceraian. Jadi, berdasarkan Pasal 95 KHI dan Pasal 136 ayat (2) KHI, pelaksanaan sita marital hanya dapat dilakukan oleh seorang suami/isteri yang masih terikat dalam ikatan perkawinan dengan cara mengajukan permohonan sita marital kepada Pengadilan Agama.

Sita marital dimohonkan oleh pihak isteri atau suami terhadap harta perkawinan baik yang bergerak atau tidak bergerak, sebagai jaminan untuk memperoleh bagiannya sehubungan dengan gugatan perceraian, agar selama proses berlangsung barang barang tersebut tidak dialihkan suami. ${ }^{24}$

Dengan demikian harta bersama dari suatu perkawinan merupakan suatu aset yang patut dan harus dijaga, baik oleh pihak suami atau isteri terhadap setiap penyimpangan yang dilakukan oleh masing-masing pihak, baik sebelum, selama atau setelah proses perceraian. Sita marital bukanlah untuk menjamin suatu tagihan uang atau penyerahan barang, melainkan menjamin agar barang yang disita tidak dijual. Jadi fungsinya adalah untuk melindungi hak pemohon selama pemeriksaan sengketa perceraian di Pengadilan berlangsung antara pemohon dan lawannya, dengan menyimpan atau membekukan barang-barang yang disita, agar jangan sampai jatuh di tangan pihak ketiga. Sita marital tidak meliputi harta pribadi, walaupun pengertian Maritaal Beslag meliputi seluruh harta kekayaan perkawinan (jadi termasuk juga harta pribadi dan harta kekayaan bersama), namun tujuan

24 Mahkamah Agung RI, Pedoman Teknis Administrasi dan Teknis Peradilan Perdata Umum dan Perdata Khusus, Buku II, Edisi 2007, (Jakarta: Mahkamah Agung RI, 2008), 85. 
pokok sita marital ditujukan ke arah harta kekayaan bersama dalam perkawinan.

Sita marital atau sita harta bersama memiliki tujuan utama untuk membekukan harta bersama suami-isteri melalui penyitaan, agar tidak berpindah kepada pihak ketiga selama proses perkara atau pembagian harta bersama berlangsung. Sita marital dimohonkan oleh pihak isteri terhadap harta perkawinan baik yang bergerak atau tidak bergerak, sebagai jaminan untuk memperoleh bagiannya sehubungan dengan gugatan perceraian, agar selama proses berlangsung barang barang tersebut tidak dialihkan suami.

Perlu diketahui sebelum proses sita marital berjalan maka oleh pemohon atau atas dasar ketua majelis hakim perlu diadakan sidang pemeriksaan setempat terhadap objek harta bersama antara suami dan istri sesuai yang tertera dalam isi gugatan agar bisa dibuktikan dengan adanya sidang di luar gedung pengadilan berdasarkan letak objek sengketa. Pemeriksaan Setempat ialah pemeriksaan mengenai perkara oleh Hakim karena jabatannya yang dilakukan di luar gedung tempat kedudukan pengadilan, agar Hakim dengan melihat sendiri memperoleh gambaran atau keterangan yang memberi kepastian tentang peristiwa-peristiwa yang menjadi sengketa. ${ }^{25}$

Berdasarkan penjelasan di atas maka penulis dapat memahami bahwa pemeriksaan perkara tersebut dilaksanakan di luar gedung pengadilan di tempat objek sengketa itu berada. Selain itu, pemeriksaan setempat berfungsi memberi keyakinan tentang peristiwa sengketa agar bermanfaat untuk mengetahui dengan jelas dan pasti tentang objek sengketa dari letak, luas, batas-batas serta dari kualitas dan kuantitas objek dimaksud, mencocokan bukti yang tertulis di persidangan dengan kondisi di tempat objek sengketa dan menghindari kesulitan ketika mengeksekusi objek sengketa, jangan sampai dinyatakan non

${ }^{25}$ Burhanudin Mokodompit, Hakim Madya Utama Pegadilan Agama Manado, Wawancara, 14 Desember 2017. 
executable atau tidak dapat dieksekusi. Setelah pemeriksaan setempat dilakukan maka hakim dapat mempunyai keyakinan yang jelas terhadap harta yang dimohonkan untuk diletakkan sita jaminan.

Untuk itu ruang lingkup penerapan sita harta bersama, jika bertitik tolak secara sempit dari ketentuan Pasal 190 KUHPerdata maupun Pasal 24 ayat (2) huruf c PP No. 9 Tahun 1975, penerapan lembaga sita marital hanya terbatas pada perkara gugatan perceraian (huwelijksontbinding). Maka proses sita marital diantaranya sebagai berikut:

a. Penggugat mengajukan permohonan sita marital bersama-sama (menjadi satu) dengan gugatannya (mengenai pokok perkara);

Penerapan sita marital yang paling utama, pada perkara perceraian. Apabila terjadi perkara perceraian antara suamiisteri, hukum memberi perlindungan kepada suami atau isteri atas keselamatan keutuhan harta bersama. Caranya dengan meletakkan sita di atas seluruh harta bersama untuk mencegah perpindahan harta itu kepada pihak ketiga. sebagaimana diatur dalam Pasal 190 maupun Pasal 125 KUHPerdata, hak untuk mengajukan sita marital, hanya diberikan kepada isteri. Hal itu sesuai dengan latar belakang yang digariskan Pasal 105 KUHPerdata yang memberi kedudukan marital macht (kepada persekutuan) kepada suami, dan sekaligus memberi hak dan wewenang kepada suami mengurus dan menguasai harta kekayaan bersama dan harta isteri dalam perkawinan. sebagai contoh dalam praktiknya, penguasaan harta kekayaan bersama berada di tangan suami hak kepada isteri meminta sita marital agar suami tidak leluasa menghabiskan harta bersama selama proses perkara masih berjalan. ${ }^{26}$

Berdasarkan penjelasan di atas maka penulis dapat menyimpulkan bahwa apa yang digariskan KUH Perdata tersebut, maka tidak ada alasan memberi hak kepada suami

${ }^{26}$ Burhanudin Mokodompit, Hakim Madya Utama Pegadilan Agama Manado, Wawancara, 14 Desember 2017. 
untuk meminta sita marital, karena harta bersama seluruhnya berada di tangannya sendiri. Persoalan terhadap sita harta bersama diperlukan apabila terjadi perkara antara suami dan isteri. Secara hukum perkara yang mungkin timbul diantara suami isteri yang erat kaitannya dengan harta bersama bukan hanya pada perkara perceraian tetapi juga pada perkara pembagian harta bersama. Seperti seorang suami yang mengajukan gugatan perceraian tanpa dibarengi tuntutan pembagian harta bersama. Terhadap gugatan itu, isteri (selaku Tergugat) tidak mengajukan gugatan rekonvensi, menuntut pembagian harta bersama, selanjutnya gugatan perceraian dikabulkan. Dalam keadaan seperti itu apabila mantan suami atau isteri ingin membagi harta bersama hanya dapat dilakukan melalui gugatan tentang pembagian harta bersama.

Dengan demikian untuk menjamin keutuhan dan keselamatan harta bersama selama proses perkara berlangsung, hanya dengan cara meletakkan proses sita marital diatasnya. Hal ini jika ditinjau dari segi penjaminan keberadaan harta bersama dalam pembagian harta bersama, sangat urgen meletakkan sita marital selama proses pemeriksaan berlangsung. Oleh karena itu sangat relevan menerapkan sita marital dalam perkara pembagian harta bersama dalam perkara perceraian.

b. Dasar alasan sita marital

Permohonan sita marital tentunya disertai alasan-alasan yang prinsipil dengan adanya kekhawatiran bahwa pihak lawan (Tergugat) akan memindahkan/menghilangkan barangbarang yang disengketakan sesuai dengan bukti-bukti dan fakta yang terjadi dalam persidangan. ${ }^{27}$

Di dalam proses perceraian, upaya menjaga harta bersama dan harta bawaan penting agar jangan sampai terlantar. Jangan sampai pula gara-gara proses perceraian itu, harta kekayaan

${ }^{27}$ Burhanudin Mokodompit, Hakim Madya Utama Pegadilan Agama Manado, Wawancara, 14 Desember 2017. 
keluarga menjadi merugikan suami atau isteri dan anak-anak mereka. $^{28}$ Tetapi dalam buku pedoman tadi disebutkan permohonan sita marital tak harus selalu dalam rangka perceraian. Bisa juga dimohonkan jika suami atau isteri melakukan 'tindakan yang mengarah pada pengalihan harta bersama'. Peraturan Pemerintah No. 9 Tahun 1975 tentang Pelaksanaan UU No. 1 Tahun 1974 tentang Perkawinan menyebutkan penggugat atau tergugat dapat meminta pengadilan untuk 'menentukan hal-hal yang perlu untuk menjamin terpeliharanya barang-barang yang menjadi hak bersama suami-isteri atau barang-barang yang menjadi hak suami atau barang-barang yang menjadi hak isteri' (Pasal 24 ayat 2 huruf $c$ ).

Berdasarkan penjelasan di atas maka penulis dapat menyimpulkan bahwa Sita ini dapat dimohonkan oleh suami atau isteri dalam sengketa perceraian, pembagian harta perkawinan, pengamanan harta perkawinan. Sita dapat diletakkan atas semua harta perkawinan yang meliputi harta suami, harta isteri dan harta bersama suami isteri yang disengketakan dalam pembagian harta bersama. Sita harta bersama ini dapat diajukan bersama-sama dalam pemeriksaan perceraian atau setelah perceraian terjadi. Selama masa sita tidak dapat dilakukan penjualan atas harta bersama untuk kepentingan keluarga kecuali dengan izin dari pengadilan Agama. Sehubungan dengan hal tersbut, maka titik berat penilaian yang harus dipertimbangkan Pengadilan atas permintaan sita marital adalah pengamanan atau perlindungan atas keberadaan harta bersama. Penilaian ini jangan terlampu dititikberatkan pada faktor dugaan atau persangkaan akan adanya upaya tergugat untuk menggelapkan barang tersebut, tetapi lebih diarahkan pada masalah pengamanan dan perlindungan harta bersama. 
c. Penetapan Majelis Hakim

Majelis Hakim mengeluarkan "penetapan" yang isinya mengabulkan atau menolak permohonan sita tersebut. Jika dikabulkan dalam penetapan itu berisi barang bergerak dan tidak bergerak terhadap harta yang diperoleh selama perkawinan yang belum dibagi cukup alasan bisa di adakan penyitaan, jika hakim menolak pasti permohonan untuk diadakan sita marital tidak cukup alasan karena tidak ada tanda atau bukti dari pihak terlawan untuk menggelapkan harta yang di dapat dalam perkawinan. ${ }^{29}$

Bahwa pengadilan dalam hal ini harus memberikan kesan bahwa lembaga pengadilan hadir untuk memberikan perlindungan hukum bagi semua pihak bukan hanya melindungi orang/pihak tertentu, hal ini harus dihindari karena dapat mengakibatkan dampak buruk bagi kehidupan masyarakat tertutama dalam soal penegakan hukum pada masyarakat. Dalam konteks Perampasan harta tergugat tersebut, dapat dikemukakan beberapa esensi fundamental sebagai landasan penerapan penyitaan yang perlu diperhatikan hal-hal sebagai berikut: ${ }^{30}$

Pertama : Sita merupakan tindakan hukum eksepsional

Sita merupakan tindakan hukum yang diambil pengadilan mendahului pemeriksaan pokok perkara atau mendahului putusan. Sering sita itu dilakukan pada saat proses pemeriksaan perkara sedang berjalan.

Kedua: Sita sebagai tindakan perampasan Pada hakikatnya penyitaan merupakan perintah perampasan atas harta sengketa atau harta kekayaan tergugat. Perintah perampasan itu, dilakukan pengadilan dalam surat penetapan berdasarkan permohonan tergugat. Perampasan harta tergugat tersebut adakalanya a.

29M. Basir, Ketua Pengadilan Agama Manado, Wawancara, Manado, 13 Desember 2017.

30Himpunan SEMA dan PERMA tahun 1951- 1997. 
Bersifat permanen Penyitaan bisa bersifat permanen, apabila penyitaan kelak dilanjutkan dengan perintah penyerahan kepada Penggugat berdasarkan putusan yang telah berkekuatan hukum tetap, atau apabila penyitaan dilanjutkan kelak dengan penjualan lelang untuk melunasi pembayaran hutang tergugat kepada penggugat. b. Bersifat temporer Penyitaan yang dilakukan atas harta sengketa atau harta kekayaan tergugat dapat dinyatakan bersifat temporer apabila hakim memerintahkan pengangkatan sita. Perintah pengangkatan sita jaminan yang seperti ini terjadi berdasarkan surat penetapan pada saat proses persidangan mulai berlangsung, dan bisa juga dilakukan hakim sekaligus pada saat menjatuhkan putusan, apabila gugatan penggugat ditolak.

Jika hal ini kita kaitkan dengan salah satu upaya yang dapat mengamankan dan menyelamatkan hak seorang isteri atas harta kekayaan perkawinan selama proses perkara masih berlangsung ialah conservatoir beslag. Upaya ini yang distukturkan dalam hukum acara perdata yang berfungsi menyelamatkan gugatan atas pihak yang berkepentingan dari kemungkinan illusoir. Bagaimana masalah sita marital dalam undang-undang perkawinan No.1/1974. Apakah dimungkinkan meletakan sita tehadap harta perkawinan. Telah disinggung dalam Pasal 24 ayat (2) huruf c PP No.9/1975. Walaupun rumusannya tidak begitu tegas, namun isi yang terkandung di dalamnya merupakan isyarat adanya hak bagi isteri atau suami untuk mengajukan permintan sita terhadap harta perkawinan selama proses perkara perceraian berlangsung dengan melihat alasan dan bukti yang lahir dalam persidangan apakah diterima atau ditolak permohonan sita.

Berdasarkan penjelasan di atas maka penulis menyimpulkan bahwa tindakan hukum yang dilakukan oleh hakim atau pengadilan sebelum melakukan perbuatan hukum 
penyitaan tentu harus tetap mempertimbangkan segala segi dalam hal ini pertimbangan hukum, keadilan dan kepatutan dan harus cermat tidak serta merta apa yang diminta oleh penggugat langsung dikabulkan pengadilan. Perlu juga menghindari kesan atau jangan menimbulkan kesan kepada pencari keadilan bahwa dengan adanya tindakan hukum sita jaminan seolah-olah pihak tergugat lemah dan pihak penggugat mempunyai bukti kuat untuk menang, hal ini tentu harus dihindari oleh pengadilan. Oleh karena itu perbuatan hukum yang dilakukan oleh hakim atau pengadilan harus cermat, adil dan patut dengan mempertimbangkan keadilan dalam masyarakat.

d. Dikabulkan sita marital

Dalam hal sita marital dikabulkan oleh Majelis Hakim, maka dalam penetapan tersebut memerintahkan kepada panitera untuk melaksanakan penyitaan tersebut. Untuk itu tindakan hukum pengadilan atas benda bergerak ataupun benda tidak bergerak milik tergugat atas permohonan penggugat untuk diawasi atau diambil untuk menjamin agar tuntutan penggugat/kewenangan penggugat tidak menjadi hampa atau dalam pengertian yang lainnya bahwa, sita marital adalah mengambil atau menahan barang-barang (harta kekayaan dari kekuasaan suami/isteri) dilakukan berdasarkan atas penetapan dan perintah Ketua Pengadilan/Ketua Majelis). menyatakan, sita marital adalah sita yang domohonkan oleh pihak isteri terhadap barang-barang suami, baik yang bergerak maupun tidak bergerak, sebagai jaminan untuk memperoleh bagiannya dengan gugatan perceraian, agar supaya selama proses berlangsung barang-barang tersebut jangan dihilangkan oleh suami. ${ }^{31}$

${ }^{3}$ Retnowulan Sutantio, Oeripkartawinata, Hukum Acara Perdata Dalam Teori dan Praktek, (Bandung: CV. Mandar Maju 2005), 52. 
Sita marital ini merupakan salah satu jenis dari sita jaminan (conservatoir beslag), sehingga pengaturannya berlaku sepenuhnya pada sita marital. Undang-undang mengatur bahwa permohonan sita marital dapat dilakukan, bila diajukan oleh penggugat selama pemeriksaan perkara berlangsung. Namun demikian, sebenarnya penggugat dapat memohonkan dilakukannya sita marital secara langsung dalam surat gugatan. Pengajuan sita marital memiliki tenggang waktu selama putusan belum dijatuhkan pada Pengadilan Tingkat Pertama, atau selama belum memperoleh kekuatan hukum tetap. Dengan pengertian bahwa jika perkaranya sudah di tingkat banding, maka permohonan diajukan pada Tingkat Banding. Kemudian, jika perkaranya di Tingkat Kasasi, maka permohonannya diajukan pada Pengadilan Tingkat Pertama. Dalam hal ini, bergantung pada pendapat Hakim yang bersangkutan, mengingat adanya perbedaan pendapat tentang sita ini. Yaitu pertama, sita merupakan kewenangan mutlak Pengadilan Tingkat Pertama. Kedua, Pengadilan Tinggilah yang berwenang memerintahkan sita kepada Pengadilan Tingkat Pertama. ${ }^{32}$

e. Proses penyitaan

Penyitaan dilakukan oleh panitera dibantu oleh 2 (dua) orang saksi, dengan membawa surat tugas. Panitera melalui Jurusita memberitahukan kepada para pihak dan Kepala Desa setempat akan dilangsungkan penyitaan, pada hari, tanggal, jam, dan tempat yang telah ditetapkan serta memerintahkan agar para pihak dan Kepala Desa tersebut hadir dalam pelaksanaan sita yang telah ditetapkan tersebut. Pada hari, tanggal yang telah ditetapkan tersebut panitera melaksanakan penyitaan, dibuatkan Berita Acara Sita, mencatat barangbarang yang disita, catatan kejadian selama penyitaan. Berita 
Acara sita tersebut ditandatangani oleh panitera (juru sita), saksi-saksi dan para pihak. ${ }^{33}$

f. Proses pemberitahuan kepada pihak yang terkait

Selanjutnya Panitera (Jurusita) memberitahukan penyitaan tersebut kepada pihak tersita dan Kepala Desa setempat (lurah setempat) selanjutnya pemeliharaan barang-barang tersita tetap berada di tangan pihak tersita.Panitera melaporkan penyitaan tersebut kepada Majelis Hakim yang memerintahkan sita tersebut dengan menyerahkan Berita Acara Sita.Penyitaan tersebut dicatat dalam Buku Register penyitaan yang ada di Pengadilan, mengenai penyitaan terhadap barang tak bergerak dan tidak bergerak selanjutnya sita marital tersebut dinyatakan sah dan berharga oleh Majelis Hakim dalam amar putusan, dikarenakan gugatannya dikabulkan. ${ }^{34}$

Pertimbangan Hukum Hakim pada Putusan Permohonan Sita Marital terhadap Harta Bersama dalam Perkara Perceraian di Pengadilan Agama Manado

Berdasarkan perkara putusan di bawah Register Perkara Nomor 0038/Pdt.G/2015/PA.Mdo. Pasal 136 ayat (2) KHI mengatur sita marital yang dilakukan selama berlangsungnya sidang perceraian. Jadi, berdasarkan Pasal 95 KHI dan Pasal 136 ayat (2) KHI, pelaksanaan sita marital hanya dapat dilakukan oleh seorang suami/istri yang masih terikat dalam ikatan perkawinan dengan cara mengajukan permohonan sita marital kepada Pengadilan Agama.

Pertama, berkaitan dengan asas ius curia novit, yakni hakim dianggap mengetahui hukum, serta berlakunya asas kebebasan hakim untuk menemukan hukumnya terhadap masalah atau kasus yang tidak terdapat peraturan hukumnya. Kedua, mendasarkan realitas yang memungkinkan seorang hakim menemukan dan menganalisis sebuah kebenaran baru atas suatu

${ }^{33}$ Rosna Ali, Panitera Muda Hukum, Wawancara, Manado, 15 Desember 2017.

${ }^{34}$ Rosna Ali, Panitera Muda Hukum, Wawancara, Manado, 15 Desember 2017. 
kasus dengan pendekatan sosiologi hukum. Pendekatan ini memungkinkan hakim melakukan penafsiran sosiologis terhadap peraturan perundang-undangan terkait agar tidak terjadi kebuntuan hukum, tetapi berkembang sesuai hukum yang dibutuhkan dan berkembang, atau disebut penemuan hukum menemukan dan menganalisis sebuah kebenaran baru atas suatu kasus dengan pendekatan sosiologi hukum..$^{35}$ Melalui pendekatan sosiologi hukum, hakim harus menggali nilai-nilai, mengikuti, dan memahami nilai-nilai hukum (kepastian hukum) dan rasa keadilan yang hidup dalam masyarakat. Sumber hukum yang dapat diterapkan oleh hakim dapat berupa peraturan perundangundangan berikut peraturan pelaksanaannya, hukum tidak tertulis (hukum adat), putusan sela, yurisprudensi, ilmu pengetahuan maupun doktrin/ajaran para ahli.

Penerapan sita marital dalam lingkungan peradilan agama telah diatur dalam berbagai bentuk peraturan perundangundangan. Pasal $823 \mathrm{Rv}$ yang berbunyi “Tindakan-tindakan yang boleh dilakukan sehubungan dengan Pasal 190 KUH Perdata adalah penyegelan, pencatatan harta kekayaan dan penilaian barang-barang, penyitaan jaminan atas barang-barang bergerak bersama atau jaminan atas barang- barang tetap bersama. ${ }^{36}$

Pencatatan harta kekayaan pasal 190 KUH Perdata sejalan juga seperti apa yang dijelaskan dalam Kompilasi Hukum Islam (KHI) juga mengatur hal yang berkaitan dengan sita marital, yaitu Pasal 95 Ayat (1) dan Ayat (2) yang menyatakan bahwa ;

1) Dengan tidak mengurangi ketentuan Pasal 24 Ayat (2) Huruf (c), Peraturan Pemerintah Nomor 9 Tahun 1975 dan Pasal 136 Ayat (2), suami atau istri dapat meminta Pengadilan Agama untuk meletakkan sita jaminan atas harta bersama tanpa adanya permohonan gugatan cerai, apabila salah satu

${ }^{35}$ Djufri Bobihu, dan Nasarudin Pampang, Hakim Madya Utama Pegadilan Agama Manado, Waw ancara, di Rungan Kantor Pengadilan Agama Manado, 16 Desember 2017.

${ }^{36}$ Burhanudin Mokodompit, Hakim Madya Utama Pegadilan Agama Manado, Wawancara, 14 Desember 2017. 
melakukan perbuatan yang merugikan dan membahayakan harta bersama seperti judi, mabuk boros dan sebagainya.

2) Dalam Pasal 136 Ayat (2) Huruf (b) Kompilasi Hukum Islam juga mengatur mengenai sita marital, bahwa : selama berlangsungnya gugatan perceraian, atas permohonan penggugat dan tergugat Pengadilan Agama dapat "Menentukan hal-hal yang perlu untuk menjamin terpeliharanya barang-barang yang menjadi hak bersama suami-istri atau barang- barang yang menjadi hak istri".

Berdasarkan hal tersebut dapat dikatakan bahwa sita marital merupakan salah satu jenis dari sita jaminan (conservatoir belslag) yang bersifat khusus, oleh karena itu segala ketentuan yang berlaku pada sita jaminan, berlaku sepenuhnya juga pada sita marital. Mulai dari pengajuan permohonan dalam surat gugatan maupun yang diajukan secara terpisah dari pokok perkaranya hingga dalam tata cara pelaksanaannya. Penerapan sita marital yang paling utama pada perkara perceraian. Apabila terjadi perkara perceraian antara suami istri, maka hukum akan memberi perlindungan kepada suami atau istri atas keselamatan keutuhan harta bersama. Dengan cara meletakkan sita di atas seluruh harta bersama untuk mencegah perpindahan harta bersama kepada pihak ketiga.

Alasan Sita Marital pada dasarnya sama dan serupa dengan sita jaminan (conservatoir beslag). Sita Marital merupakan perwujudan sita jaminan. Berdasarkan isyarat ketentuan pasal 215 ayat $1 \mathrm{KUH}$ Perdata tersebut tak mengurangi keleluasaan istri untuk mengamankan haknya dengan mempergunakan upayaupaya seperti yang telah di atur dalam ketentuan hukum acara perdata. Jika hal ini kita kaitkan dengan salah satu upaya yang dapat mengamankan dan menyelamatkan hak seorang istri atas harta kekayaan perkawinan selama proses perkara masih berlangsung ialah conservatoir beslag. Upaya ini yang distrukturkan dalam hukum acara perdata yang berfungsi menyelamatkan gugatan atas pihak yang berkepentingan. 
Ketentuan pasal 24 ayat 2 huruf c PP No.9 Tahun 1975 tersebut menjelaskan bahwa "Selama berlangsungnya gugatan perceraian atas permohonan penggugat atau tergugat pengadilan dapat menentukan hal-hal yang perlu untuk menjamin terpeliharanya barang-barang yang menjadi hak bersama suami istri atau barang-barang yang menjadi hak istri".

Seperti yang disinggung di atas rumusan pasal ini memang kurang jelas mengarah kepada upaya tindakan penyitaan harta perkawinan. Akan tetapi dengan memperlihatkan kalimat menentukan hal-hal yang perlu untuk menjamin terpeliharanya barang-barang, pada hakikatnya sudah tersirat makna tindakan atau upaya penyitaan terhadap harta perkawinan dan tindakan yang dianggap dapat menjamin harta perkawinan selama proses perkara perceraian berlangsung adalah sita jaminan (conservatoir beslag) yang disebut Sita Marital. Dengan demikian maksud yang terkandung dalam pasal 24 ayat 2 huruf c memberi hak kepada suami istri untuk mengajukan Sita Marital atas harta perkawinan selama proses perkara perceraian berlangsung, dan Pengadilan berwenang untuk mengabulkan Sita Marital agar terjamin pemeliharaan dan keutuhan harta perkawinan selama proses perkara perceraian masih berlangsung. Untuk itu dengan berpijak pada putusan sela tentang sita jaminan terhadap harta bersama di atas maka penulis menyimpulkan permohonan sita jaminan terhadap harta bersama di atas tidak dikabulkan oleh majelis hakim bahkan ditolak sesuai dengan pertimbangan hukum hakim dengan melihat fakta-fakta yang timbul dalam persidangan yang paling pokok adalah tergugat mengaku bulat-bulat di depan persidangan tidak menggelapkan, menjual atau memindahtangankan kepada pihak ketiga atau pihak lain terhadap harta bersama yang didapat dalam perkawinan.

Pembuktian dalam proses perdata adalah upaya yang dilakukan oleh para pihak untuk menyelesaikan persengketaan mereka atau untuk memberi kepastian tentang benar terjadinya peristiwa hukum tertentu, dengan menggunakan alat bukti yang 
ditentukan hukum, sehingga dapat dihasilkan suatu penetapan atau putusan oleh pengadilan. ${ }^{37}$ Dalam hal ini secara hukum materiil sudah terpenuhi bahkan hakim Pengadilan Agama Manado menolak sita jaminan yang diajukan. Dasar hukumnya Pasal 174-176 HIR, Pasal 311-313 Rbg, dan Pasal 1923-1928 BW. Selain alat bukti, maka pengakuan merupakan salah satu yang dipertimbangkan dalam persidangan. Pengakuan merupakan keterangan sepihak yang tidak memerlukan persetujuan lawan, baik secara lisan maupun tertulis yang harus dinyatakan secara tegas oleh salah satu pihak dalam persidangan, yang membenarkan baik seluruhnya atau sebagian dari suatu peristiwa, hak atau hubungan hukum yang diajukan oleh lawannya yang mengakibatkan pemeriksaan lebih lanjut oleh hakim tidak perlu dilakukan.

Pengakuan yang telah diberikan oleh pihak lawan dan sebagai pendukung sidang pemeriksaan setempat mengenai harta bersama yang termuat dalam isi gugatan sesuai dan tidak berindikasi berkurang atau digelapkan menyebabkan berakhirnya suatu perkara dalam peletakan sita, sehingga tidak diperlukan lagi kelanjutan pemeriksaan dan lawan tidak perlu membuktikan dalilnya. Hakim dapat membuat putusan berdasarkan pengakuan tersebut. Hal ini sesuai dengan tujuan hukum acara perdata yaitu untuk mencari kebenaran formal, dengan demikian hakim membuat putusan sela dengan menolak sita jaminan terhadap harta bersama dalam perkara perceraian.

\section{Penutup}

Berdasarkan fakta-fakta yang terjadi di Pengadilan Agama Manado mengenai proses penyelesaian permohonan sita marital terhadap harta bersama dalam perkara perceraian dengan melihat dari tahapan-tahannya yaitu permohonan peletakan sita marital terhadap objek baik barang bergerak maupun tidak bergerak

${ }^{37}$ Achmad Ali dan Wiwie Heryani, Asas-asas Hukum Pembuktian Perdata, (Jakarta: Kencana Predana Media Group, 20I2), 21 . 
sangat bergantung pada alasan yang kongkrit dan dapat dibuktikan mengenai peletakan sita dimuka persidangan, dengan demikian apabila permohonan sita dapat dikabulkan oleh majelis hakim sesuai bukti yang kuat dan lahir dalam persidangan maka majelis hakim dapat meletakkan sita dengan memerintahkan Panitera dan dibantu oleh jurusita untuk melakukan sita baik barang bergerak atau tidak bergerak untuk dicatat dan selanjutnya panitera membuat berita acara sita yang terdapat dalam objek sengketa dalam isi gugatan dengan dihadirkannya pemerintah setempat.

Pertimbangan hukum hakim mengenai peletakan sita marital tidak serta merta diputuskan begitu saja akan tetapi majelis hakim terlebih dahulu melihat pada fakta-fakta yang lahir dalam persidangan apabila sita dikabulkan maka cukup alasannya bagi pemohon sita untuk diletakkan sita marital dan apabila permohonan sita ditolak maka tidak cukup alasan untuk diadakan peletakkan sita marital oleh majelis hakim karena mereka berpendapat tidak ditemukan kekhawatiran bahwa tergugat akan memindahkan atau mengalihkan objek sengketa kepada orang lain, semuanya itu didukung oleh sidang diluar gedung Pengadilan Agama Manado yang dinamakan dengan sidang pemeriksaan setempat, dengan melihat apakah objek yang termuat dalam gugatan benar menurut hukum atau ada hal-hal yang berindikasi tidak sesuai dengan objek yang termuat dalam gugatan mengenai harta bersama baik barang bergerak atau tidak bergerak.

\section{Daftar Pustaka}

R. Soesilo, Subekti. Kitab Undang-Undang Hukum Perdata, Bandung: Pradnya Paramita.

A. Rasyid, Roihan. Hukum Acara Peradilan Agama, Cet.2; Jakarta:

PT. Raja Grafindo Persada, 2003. 
Ali, Achmad dan Wiwie Heryani, Asas-asas Hukum Pembuktian Perdata, Jakarta: Kencana Predana Media Group, 2012.

Djufri Bobihu, S.Ag, SH. dan Drs Nasarudin Pampang, Hakim Madya Utama Pegadilan Agama Manado, Wawancara, di Rungan Kantor Pengadilan Agama Manado, 16 Desember 2017.

Dr. M. Basir., MH, Ketua Pegadilan Agama Manado, Wawancara, Manado, 13 Desember 2017.

Drs. Burhanudin Mokodompit, Hakim Madya Utama Pegadilan Agama Manado, Wawancara, 14 Desember 2017.

Harahap, M Yahya. Hukum Acara Perdata, Jakarta: Sinar Grafika, 2010.

Harahap, M Yahya. Hukum Acara Perdata: Permasalahan dan Penerapan Conservatoir Beslag (Sita Jaminan), Cet. 1; Jakarta : Pustaka, 1987.

Himpunan SEMA dan PERMA tahun 1951-1997.

http://Atmajaya.ac.id. 2015. Tinjauan Yuridis Gugatan Sita Marital terhadap Harta Bersama menurut Peraturan Hukum di Indonesia. https://lib.atmajaya.ac.id/default.aspx? tabID=61\&src=k\&id=155074. Diakses 9 Mei 2017.

Lembaran Negara RI, Undang-undang No. 1 Tahun 1974 tentang Perkawinan Pasal 35

Lembaran Negara RI, Peratutan Pemerintah No. 9 Tahun 197 Tentang Gugatan Perceraian

Lembaran Negara RI, Undang-Undang Nomor 1 Tahun 1974 Tentang Perkawinan.

Mahkamah Agung RI, Pedoman Teknis Administrasi dan Teknis Peradilan Perdata Umum dan Perdata Khusus, Buku II, Edisi 2007, Jakarta: Mahkamah Agung RI, 2008.

Manan, Abdul. Penerapan Hukum Acara Perdata di Lingkungan Peradilan Agama, Cet. 4; Jakarta: Kencana, 2006.

Mertokusumo, Sudikno. Hukum Acara Perdata Indonesia, Cet. 2; Yogyakarta: Liberty, 1999.

Rosna Ali, S.Ag, Panitera Muda Hukum, Wawancara, Manado, 15 Desember 2017. 
Sudarsono, Hukum Perkawinan Nasional, Jakarta: Rineka Cipta, 2005.

Susilo, Budi. Prosedur Gugatan Cerai, Yogyakarta: Pustaka Yustisia, 2007.

Sutantio, Retnowulan, Oeripkartawinata, Hukum Acara Perdata Dalam Teori dan Praktek, Bandung: CV. Mandar Maju 2005. 